\title{
CITY DWELLERS' PERCEPTION OF ENVIRONMENTAL HAZARDS AND RISKS IN DHAKA CITY
}

\author{
SHAHADAT BASER AND M. MAKSUDUR RAHMAN \\ Department of Geography and Environment, University of Dhaka, \\ Dhaka-1000, Bangladesh
}

\begin{abstract}
This paper examines the social perceptions against the existing overall environmental hazards and pollutions of different residential areas of Dhaka Metropolitan area. The empirical data have been collected through a semi-structured questionnaire from 180 households. The findings reveal that more than $60 \%$ of people in residential areas are at high risk for environmental hazards due to the vast population density and unplanned high-rise buildings. Furthermore, on average, more than $53 \%$ of respondents have uttered various pollutions emphatically air, dust and noise pollution which are now common environmental phenomena of residential areas for unruly behaviors of dwellers and mismanagement of respective authorities. Moreover, the lack of open space is a burning question for the city dwellers, which causes a ventilation crisis through accelerating indoor pollution claimed by $95 \%$ of slum dwellers. After all, slum dwellers are more deprived of overall urban facilities, and abiding in unhygienic conditions made them more prone to fire hazards and severe health disorders. So, the study suggests that policymakers and city corporation authorities should be more concerned and taken proper initiatives to eradicate multifaceted issues to fabricate a sustainable environment for city dwellers.
\end{abstract}

Key words: Environmental hazard, Risk/ Pollution, Social perception, Slum, Dhaka city.

\section{Introduction}

In most urban cities of developing countries, the ever-growing population and its evolving nature have resulted in dramatic shifts in the current pattern of land use in and around those cities, thereby impacting the environment of the city (Rout and Bhagat 2012). Because urbanization has now become one of the world's major environmental challenges (Dewan et al. 2012). The world's urban population has risen rapidly from 751 million to 4.2 billion within 1950-2018, where 54\% live in Asia (United Nations 2019). As a result, the cities are increasingly overcrowded and spoiled worldwide (Blanco et al. 2009, McDonald et al. 2010, Wolch et al. 2014). Due to the absence of sustainable

*Corresponding author: <shahadat.baser@gmail.com>. 
urban environment maintenance strategies, the cities are facing difficulties related to environment pollution, transport system, housing issues, health infrastructure and other civic amenities and services (Rout and Bhagat 2012). Notwithstanding, the urban areas particularly have the high potentiality of losses from natural hazards ( Dewan et al. 2012, Brecht et al. 2013) owing to uncontrollable growth of population and mismanagement of urban services (Bhattarai and Conway 2010, Islam et al. 2014).

Dhaka, as capital and the fastest-growing megacity of Bangladesh, has higher inbound traffic on roads, increasing energy consumptions, vast waste generations, and scarcity of proper performance of environmental rules and regulations rising the emission of pollutants into the air ${ }^{1}$, water, and soil (Hosamane and Desai 2007, Alam 2009, Parvin et al. 2013, Ahmed 2014). According to World Health Organisation (WHO) 2018, Dhaka is the worst air polluted city among the top 20 cities in the world. The air quality and urban environment have weakened over the last decade for radical change in emissions from vehicle exhaust ${ }^{2}$, growing congestion, the vast emerging of industrial activities, construction activities and brick kilns, road dust, residential and commercial biomass burning, waste burning, and diesel generators (Habib and Alam 2003, Guttikunda et al. 2013, World Health Organization 2014, Balakrishnan et al. 2019). Dhaka is also marked for a tremendous scarcity of outdoor facilities due to unplanned growth and has the lowest per capita number of open spaces ${ }^{3}$ although the city's lungs are open spaces (Hossain 2006, Khan 2014). According to Dewan et al. (2012) and Islam et al. (2014), severe environmental pollution issues result from urbanization in terms of changes in land usage, the inadequacy of settlements, lack of water and sanitation services, and degradation of the community's ambient environment. Such studies concentrate mainly on the problems of land use change and its environmental effects in the city.

Research has also considered the perceptions of urban residents regarding the community environment and quality of life. An emphasis was given to define what variables ultimately differentiate or affect how people perceive their quality of life (Islam et al. 2014). A dynamic combination of variables including intellect and emotion is responsible for people's perception of environmental risks and hazards. Understanding perceptions

1 Air pollutants, such as carbon monoxide (CO), $\mathrm{CO}_{2}, \mathrm{NO}_{2}$, nitrogen oxides ( $\mathrm{NOx}$ ), sulfur dioxide ( $\mathrm{SO} 2$ ), ozone (O3), Lead (pb) heavy metals, volatile organic compounds (VOCs), and irrespirable particulate matter (PM2.5 and PM10) (Begum et al. 2010, Kampa and Castanas 2008, Salam et al. 2008, Hosamane and Desai 2007, Goyal et al. 2006, Akimoto 2003). Vehicle exhaust- motorcycles, Private cars, aged busses, passenger cars, three-wheeler passenger vehicles, commercial vans, and freight trucks (Guttikunda et al. 2013, Habib and Alam 2003).

3 "Playgrounds, stadiums, parks, woods, swimming pools, public libraries, theatres, art galleries, exhibition halls, museums and so on" (Hossain 2006). 
means exploring individuals' knowledge, thoughts, and attitudes about their environment (Olowoporoku 2018). On the other hand, different residents have distinct perceptions over the various environmental issues through human actions that are primarily responsible for the worse environment directly or indirectly. According to Rahman et al. (2010), in higher-income neighborhoods, families are typically well placed not only in terms of coping with issues of family size, but also with issues of community level. The contrary is true for the urban poor living in low-income areas, where conditions at the community level will exacerbate issues seen at the level of the home. Local issues are further exacerbated, where the vulnerable homes, most especially but not solely in informal communities, are poorly provided with basic facilities and services. Furthermore, the unsuitable spatial planning and control of the scarce resources is accused of further impeding Dhaka's socio-environmental parameters (Dewan et al. 2012).

Several research studies of urban dwellers' perceptions on environmental hazards and risks in Dhaka City or its particular area have already been carried out by Maniruzzaman and Haque 2007, Paul and Bhuiyan 2010, Rahman et al. 2010 (Chattogram), Dewan et al. 2012, Islam et al. 2014, Khan et al. 2018, Khatun and Islam, 2015, Rahman et al. 2018. However, this is the first attempt to study urban resident perceptions by addressing highincome, middle-income, and slum dwellers of the Dhaka Metropolitan Area (DMA). So, this paper's main thrust is to identify and assess the social perceptions/ behaviors against the existing overall environmental hazards and risks/ pollutions of urban residential areas in DMA. In addition, the study will also try to determine the influencing factors responsible for creating urban residential problems within the study areas.

\section{Materials and Methods}

Selection of the study area: Dhaka Metropolitan Area (DMA) was chosen as the study area for aggregation of the vast population in residential zones. There are various types of residential areas such as high-income, upper middle-income, middle-income, lower middle-income and also some sorts of mixed-up residential areas. That's why to extract the attitudes towards environmental hazards and risks (earthquake, fire, waterlogging, pollution) through different perspectives (Khatun and Islam 2015), three distinct residential areas were selected purposively which are situated nearly each other (Fig. 1). Dhanmondi $(10,11$, and 12) have been selected for high-income residential areas, which is also recognized as the first planned residential area in Dhaka city developed by the Public Works Department in the 1960s. The area is the nearly central part of the city, and 
a total of $2.179 \mathrm{~km}^{2}$ is designed with a grid pattern plan with the road (Haque \& Asami, 2011). Another area is Mirpur Pallabi 11 1/2, selected as a middle-income residential area near the Rupnagar and Eastern Pallabi and under Dhaka North City Corporation (DNCC). Our study area occupies about $2 \mathrm{~km}^{2}$ area. The other is the Kallayanpur slum area known as Kallayanpur Pora Bastee and a low-income residential area situated at Kallayanpur mahalla under the Kallayanpur ward of Mirpur Thana. Furthermore, slum dwellers are the most affected victims for the hazards and risks. To fulfill the objectives of the study, the following activities were undertaken.

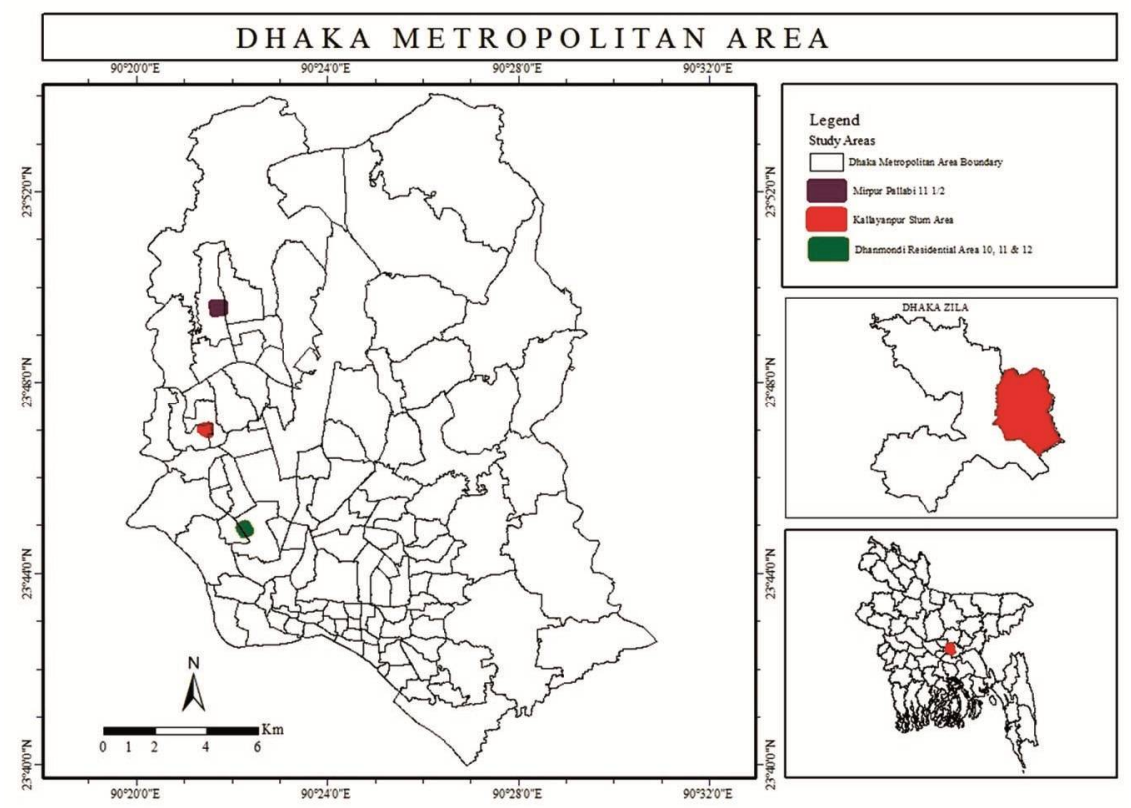

Fig. 1. Location of the study areas in the Dhaka Metropolitan Area.

Source: Field Study, 2018

Primary data collection: Data were collected in 2018 from the selected residential areas through maintaining various processes. A quantitative approach was used to collect data for this study. A detailed semi-structured questionnaire survey was carried out within those areas to collect primary data. The questionnaire was developed based on residents' experiences. In addition, discussions with various researchers were added and also negotiated with experts on this field. Hence, to demonstrate any mistakes or contradictions, it was essential to pre-test our new questionnaire and determined whether it would produce valuable results that would lead to the study's objectives. The pilot survey was carried out with residents before to the main study. Some minor difficulties 
with the text and sequencing of two issues were found, which were well addressed before the key research.

Each questionnaire was translated in Bengali from English so that the residents can understand and respond fruitfully. A face-to-face questionnaire survey was conducted, which is the most effective method for data collection (Bird et al. 2009). For the selection of the participants, a purposive, systematic sampling technique was used due to some difficulties that occurred during data collection. Because most residents of high- and middle-income residential areas were unwilling to interview and share their views and perceptions with researchers on account of their tight schedule of businesses, jobs and also for feeling insecurity with unknown persons. In some apartment buildings, it was strongly prohibited for outsiders to enter the gate. As a consequence, the normal sampling interval varies in study areas. For example, each 4th household was selected in certain residential areas, while every 10th household was selected in another area. But such kinds of problems did not take place in slum areas. However, each participant was told of the purpose and the potential use of the dataset before to the interview. They were also told that, at any given time, they were entitled to withdraw from the survey without repercussions. Households' heads over 20 years old and living here more than 5 years were targeted, and anonymity was ensured for all participants. In the absence of the household head, an adult member of the household was interviewed. A total of 180 households (60 households from each area) were studied to assess their perceptions/ behaviors against environmental risks, pollutions, and other scarcities. An in-depth study was conducted to know their assistance from city corporations, NGOs, and health care facilities.

Secondary data collection: The secondary data were collected from government and nongovernment official documents and statistics, yearly reports, various published books, research papers, journals, articles, daily newspapers, and web-based documents to know the background and existing knowledge.

Data processing and analysis: All types of data were collected carefully. All the questions were asked to know the perceptions of the dwellers. Their responses on various hazards and risks were assessed using a 1-5 Likert scale, where 1 means the lowest probability or no risk and 5 signifies very risk or the highest. Apart from that, associated questions were also analyzed to explore the related intensities. Furthermore, the collected data were analyzed by computer-based specific statistical software MS excel 2016. The map of the study areas on different aspects is prepared using Arc GIS 10.4. The analysis has been presented using descriptive statistics. 


\section{Results and Discussion}

Environmental hazards: Most urban areas are highly vulnerable to earthquakes, fire, and waterlogging/ flash floods because of unorganized settlements and large aggregation of the population (Karim 1995). The study found that about $64 \%$ of Dhanmondi respondents and $70 \%$ of the Mirpur area claimed very risky for earthquakes due to the vast density of both population and buildings, causing a significant loss of properties and lives. On the contrary, more than $85 \%$ of slum dwellers uttered low risk in the Kallayanpur slum (Fig. 2) due to the absence of high-rise buildings except for compact shanty settlements. But all the slum dwellers (also known as Pora Bastee) claimed that fire is the most significant hazard and life-threatening issue because they recently faced a destructive fire in January 2016 (The Daily Star 2016b) a day ago suspended eviction from High court. Several slum-dwellers alleged that the ruling party men set the shanties on fire to complete their eviction for benefitting from different projects within the land if thrown off (The Daily Star 2016a). Slums are unplanned and lack of emergency response in fire (Claret et al. 2012, Thomas 2007). Contrarily, 70\% of people Dhanmondi R/A (Fig. 2) have voiced very risky for crowded settlements and descript electric wiring, which can be devastated within no time by fire. But, Mirpur Pallabi uttered moderately hazardous areas (Alam and Baroi 2004) due to maintaining zonal policies and regulations.

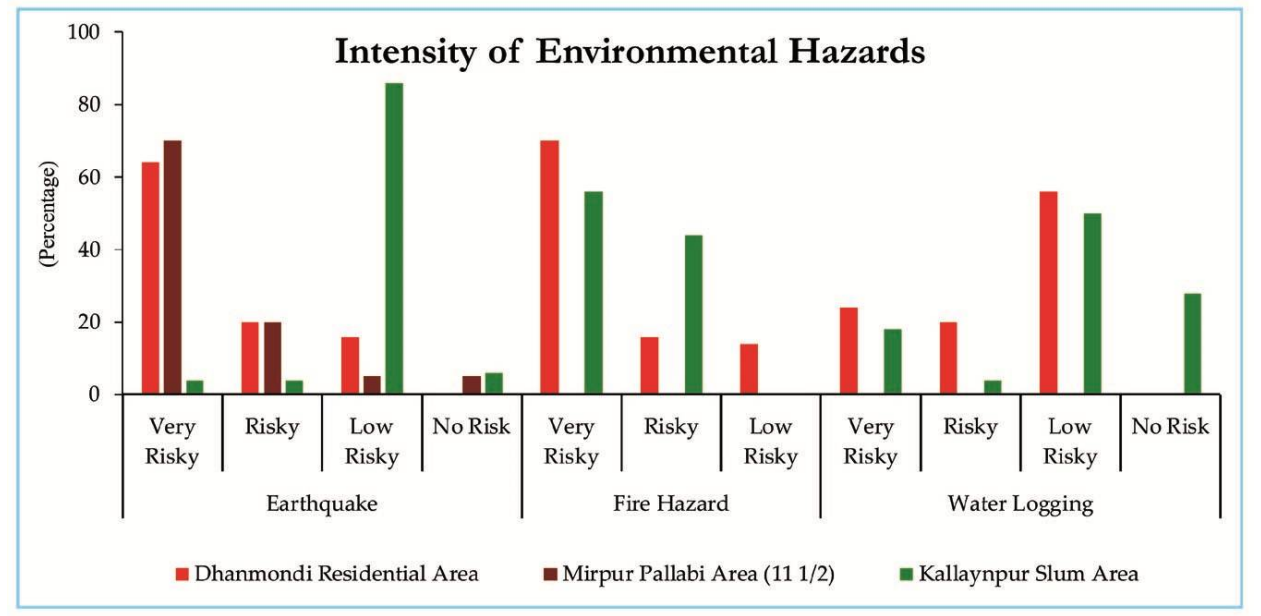

Fig. 2. A comparative scenario of the intensity of environmental risks. Source: Field Study, 2018

Waterlogging problems have become more and more severe in urban areas for excessive rainfall (Alam and Rabbani, 2007, Mark et al. 2018, Zhang et al. 2012). Besides, the blockage of drainage and sewerage systems for solid waste dumping creates a massive 
waterlogging problem, which is the main reason for mosquito growth and associated diseases (Rasid 1996, Ahmed et al. 2007, Islam et al. 2010). Moreover, waterlogging is the combination of physical, social, environmental problems and economic burden which directly affects poor dwellers (Mowla and Islam 2013) and also communication sector, schools, garment factories, etc. (Alam and Rabbani 2007). The study explored that waterlogging is not a very big problem, but in the rainy season, it becomes terrible in Dhanmondi, Mirpur, and Kallayanpur slum area responded by overall $20 \%$ people (Fig.1). Moreover, Slum areas of Bangladesh where dwellers have to confront water stagnation by excessive rainfall for narrow and unpaved roads (Kamruzzaman and Hakim 2016). Only $10 \%$ of slums had a good drainage system to avoid waterlogging, but Dhaka and Chattogram had the worst drainage conditions (Islam et al. 2006, Mohit 2012).

Uneven sewerage system: The sewerage system is the crucial element of amenities encompasses various components such as receiving drains, utility holes, pumping stations, storm overflows, and screening chambers of the combined sewer or sanitary sewer (Hassan et al. 2017). The study revealed that the sewerage system is well organized in Dhanmondi R/A, where a hundred percent of dwellers use a septic tank. The quality of the sewerage system in Pallabi is also well enough where more than 85 percent of residents use a septic tank for their houses which is an excellent sign for an ideal sewerage system (Fig. 3). Apart from 6\% of people use integrate sewerage system. But in the Kallayanpur slum, the situation has been developed recently. At present, about $42 \%$ of households use the septic tank, and $48 \%$ use integrated sewerage systems (Fig. 3). The rest of the sewerage lines are connected to the drainage line of the Kallayanpur slum, which creates a severe problem for all the slum dwellers. Because of narrow roads and inadequate drainage systems, waterlogging and flash floods occur around their houses during the rainy season (Ahmed 2014, Braun and Aßheuer 2011, Farah et al. 2015, Islam et al. 2006, Kamruzzaman and Hakim 2016). Furthermore, for waterlogging, the sanitation system got affected. Water supplied line become polluted and unavailable for use and flares various water-borne diseases like diarrhoea, typhoid, cholera, skin diseases, fever, asthma, jaundice which affected Kallayanpur slum dwellers seasonally (Ahmed 2014, Dana 2011, Farah et al. 2015, Gulis et al. 2004, Kamruzzaman and Hakim 2016, Latif et al. 2016).

Menace problem: According to Islam et al. (2010), 38.4\% of inhabitants claimed that waterlogging is the main reason for mosquitos' growth. Without that, cemented tanks, bathtubs, septic tanks, unused wells, derelict ponds, polluted canals, and open water containers serve as real heaven for mosquito breeding (Bashar et al. 2006, Chepesiuk 2003, Khan et al. 2014, Snehalatha et al. 2003). Furthermore, the study revealed that $60 \%$ 
of households claimed mosquito as a very severe problem (Fig. 4a) which was not so severe before ten years.

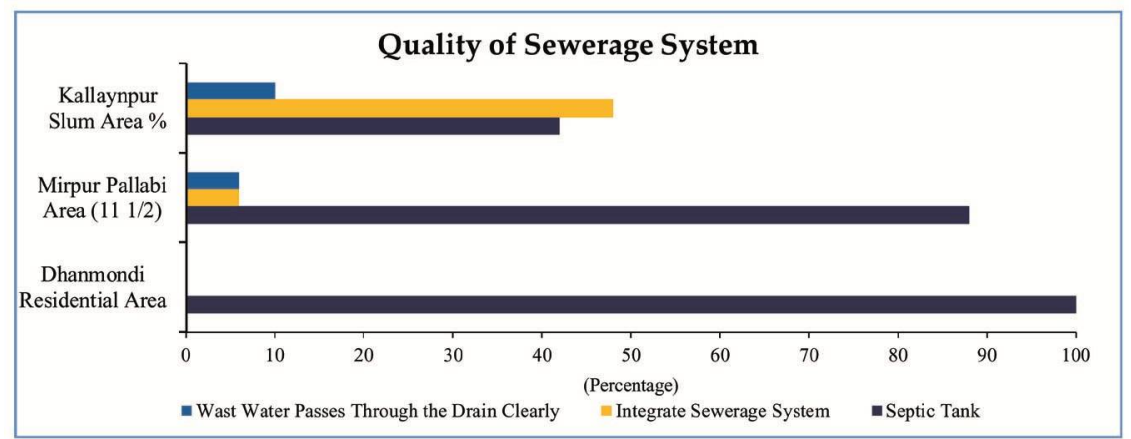

Fig. 3. Comparative study of quality of sewerage system Source: Field Study, 2018
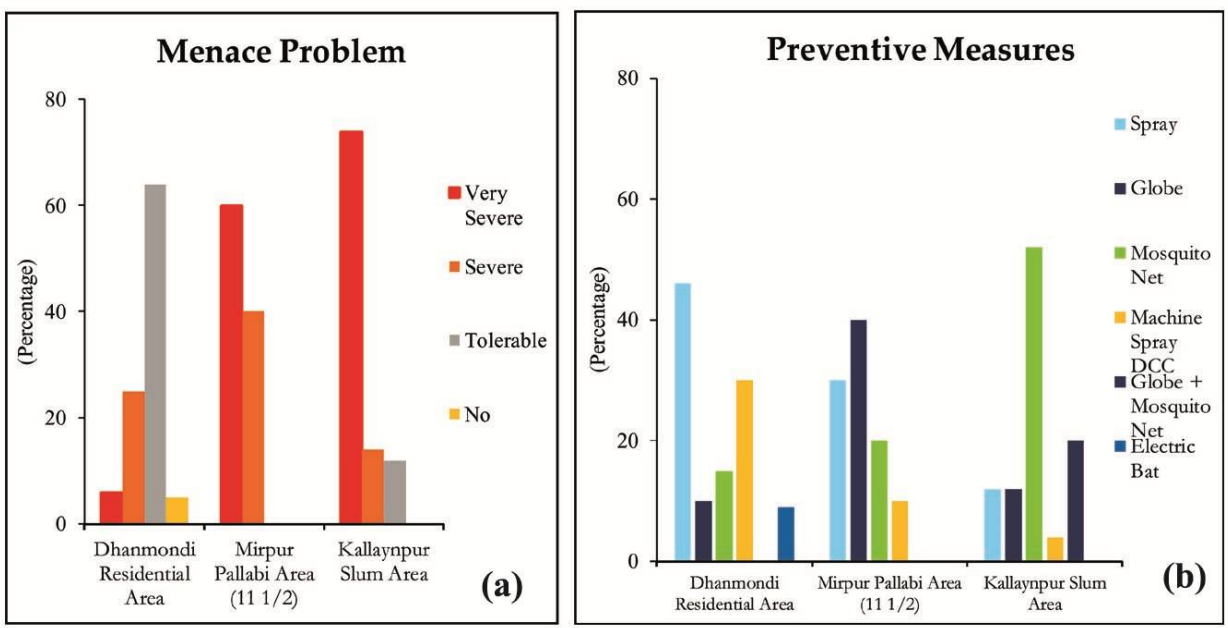

Figure 4. Comparative scenario of a mosquito problem and alternative measures. Source: Field Study, 2018.

But in the Kallayanpur slum, the mosquito problem is more severe than in other residential areas, which is urged by $74 \%$ of slum dwellers, wherein Dhanmondi R/A only $6 \%$ (Fig. 4a). Now various mosquito-borne diseases have become a leading health problem in Bangladesh (Bashar et al. 2006, Snehalatha et al. 2003). Dengue fever, chikungunya fever, yellow fever, hemorrhagic fever, malaria are the prime mosquitoborne diseases (Bashar 2006, Bashar et al. 2006, 2012, Chowdhury et al. 2012, Gautam et al. 2017, Halstead 1966, Hassan et al. 2014, Khan et al. 2014). The study also found 
that $62 \%$ uttered Chikungunya ${ }^{4}$ as a devastating epidemic in Kallayanpur slum where only $26 \%$ claimed dengue fever is caused by Aedes aegypti and Aedes albopictus mosquitoes (Bashar et al. 2014, Hassan et al. 2014).

Figure $4 \mathrm{~b}$ shows that more than $50 \%$ of slum dwellers use mosquito nets and $20 \%$ use globe/coil as preventive measures for protection from the menace. This behavior is also similar in the Pallabi area, where $60 \%$ use both globe and mosquito net. But in Dhanmondi R/A, more than $45 \%$ of households use Aerosol spray and also get the facility of Machine spray from DCC (Fig. 4b). According to Dhar-Chowdhury et al. (2016), the DCC authority has periodic programs of spraying larvicides (e.g., DDT) and insecticide pesticides (e.g., fenthion, Malathion) where this facility is very rare in slum areas but emerging in Mirpur Pallabi.

Major environmental risks: As the fastest-growing megacity of the world, Dhaka city contains more than 20 million people (United Nations 2019), and every year millions of people are added from the different parts of Bangladesh. These enormous populations have an extra burden on the residential areas of the Dhaka Metropolitan area and accelerating the pollution day by day. The study explored that Dhanmondi R/A (after being planned and agglomeration of high-income people), the intensity of air pollution, noise pollution, and dust pollution are very severe claimed by $44 \%, 56 \%$ and $60 \%$ of households, respectively (Fig. 5) due to congestion of commercial, residential and institutional buildings; motorized vehicles, construction works and indiscriminate use of loudspeaker (Alam 2009). Respondents also added that pollution level is magnifying because of the maintenance disorder in public facilities and proper implementation of law enforcement. In the Mirpur Pallabi area, these problems are significantly serious because of the ongoing construction activities where $58 \%$ of households urged dust pollution, and $32 \%$ encouraged air pollution. But $48 \%$ of people claimed noise pollution is moderately high because of this common problem. Contrarily in the Kallayanpur slum, the study revealed that more than $55 \%$ of households are fronting very severe dust pollution and air and noise pollution, respectively (Fig. 5) due to congestion, burning solid fuels for cooking which are wood, papers, and elastic and plastic wastes and noisy behaviorof the dwellers. These pollutions (basically air pollution) lead to fatalities and severe health diseases like acute lower respiratory infections, cardiovascular disease, lung cancer, and diabetes (Alam 2009, Guttikunda and Goel 2013, Hosamane and Desai 2007).

4 "Chikungunya is characterized by fever, nausea, fatigue, myalgia, headache, rashes, prolonged joint pain, and arthralgia" (Gautam et al. 2017). 
On the other hand, water quality issues are a significant challenge that humanity faces every day in this century (Schwarzenbach et al. 2010) where surface water is more prone to contamination due to the availability of sewage and wastewater particularly in Dhaka city (Islam et al. 2015b). The study revealed different scenarios from the study areas.

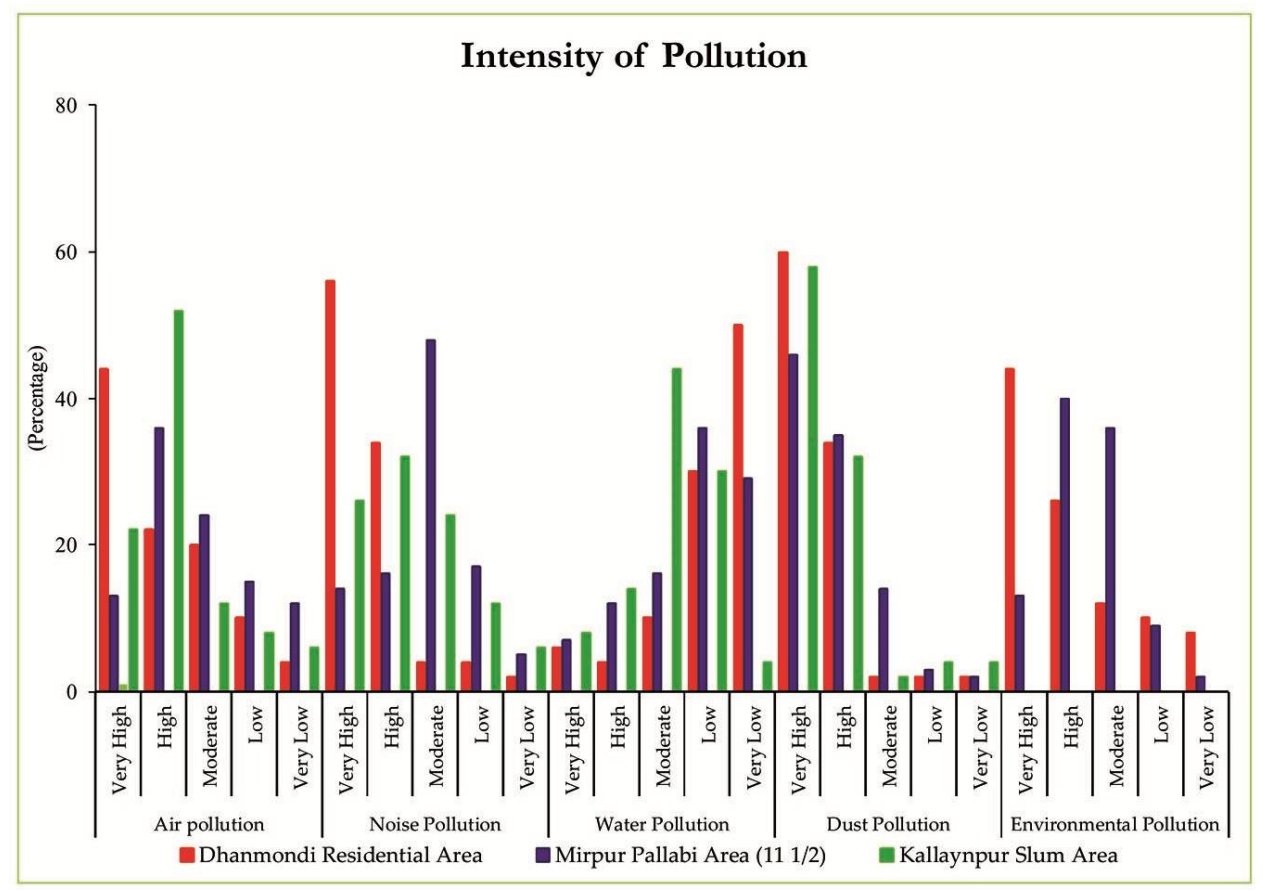

Fig. 5. The comparative scenario of pollutions as perceived by the respondents. Source: Field Study, 2018

For being high to middle-income group residential area, about $80 \%$ and $56 \%$ of Dhanmondi R/A and Mirpur Pallabi area' s household respondents claimed that they have very few issues on water pollution (Fig. 5). This is because they are well supplied by WASA and for existing developed sewerage system. But in the Kallayanpur slum, despite existing contaminated pond by waste disposal, unplanned utility services, and sanitation infrastructure (Akanda and Hossain 2012), maximum respondents (about 75\%) said that they have moderate water pollution because they are habituated to use polluted water and to wait on a queue for a long time due to collect drinking water supplied by WASA vehicle only in the morning. Using contaminated water causes various health diseases, including skin, diarrhea, malaria, cholera, dysentery, bacterial origin typhoid 
fever, and yellow fever (Akanda and Hossain 2012, Halder and Islam 2015, Islam et al. 2010; Talukdar et al. 2013).

Indoor pollution: In residential areas, along with other pollutions, indoor pollution is boosting up day by day due to lack of ventilation facilities. Becasue the high density of settlements affects the accessibility of natural agents (natural lighting, views, ventilation, etc.) for domestic services (Chen et al. 2008). The lack of ventilation, low lighting and barrier loaded kitchens and bathroom facilities are hamper residential satisfaction in Dhaka Metropolitan Area (Boadi et al. 2005, Phillips et al. 2004, Sheuya 2008). The research revealed a significant absence of ventilation facilities in Kallayanpur Slum, where $95 \%$ of residents claimed no sufficient ventilation (Fig. 6). The situation is extremely vulnerable because of overcrowding and congestion, low-quality building structure (materials like wood, bamboo, straw, thatch or tins, and scraps, etc.), no separate place for cooking (creates high levels of indoor air pollution), lack of ventilation, lighting, sanitation facilities (Agarwal and Taneja 2005, Sheuya 2008, Alamgir et al. 2009, Jahan 2012) which are pernicious to safety, health and morals (Marimuthu et al. 2016, Sundari 2003). On the contrary, Dhanmondi and Mirpur Pallabi get incredible sufficient ventilation claimed by $70-76 \%$ of residents (Fig. 6). Most apartment holders gave the highest priority to water facilities and adequate ventilation (Kamal and Pramanik 2015).

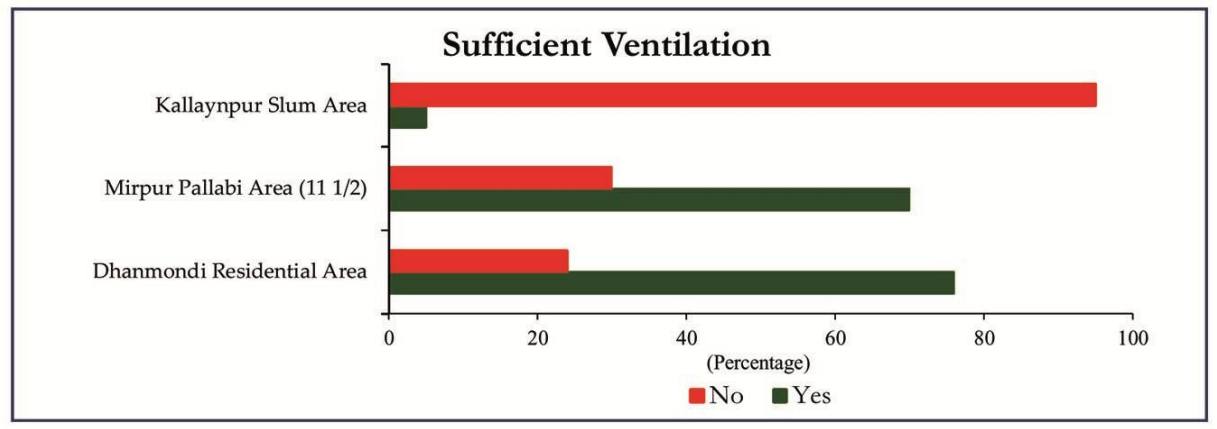

Fig. 6. The comparative scenario of ventilation facility. Source: Field Study, 2018

Open space: Ventilation facilities are primarily dependent on the availability of open space, which is diminishing at an alarming rate. At present, Dhaka's urban infrastructure is highly vulnerable due to overpopulation. Dhaka city has $21.57 \%$ open space, of which city parks involve $0.89 \%$, urban ranger service $0.02 \%$, gardens $0.90 \%$, and $12.12 \%$ has a place with agriculture (Islam et al. 2015a, Rahman and Siddiquee 2012). For these 
reasons, the city dwellers are not well privileged with urban open space everywhere in the city. Therefore, open space which exists represents highly unequal distribution.

The study has been conducted to know the satisfactory level of city dwellers in those particular study areas. Figure 7 shows that 78 percent of dwellers of Dhanmondi R/A are moderately satisfied and only $8 \%$ are satisfied with the existence of Dhanmondi lake (as a recreational place) and some playgrounds (especially for children). Abahani Playground is located in that area which is recognized as an open space for recreation but for a limited time. At the same time, in Mirpur area, more than $70 \%$ of people are satisfied, and about 25 percent of dwellers are more satisfied because of close to the National Zoo, Botanical garden \& National Stadium and adjacent of playgrounds to their buildings and locality. But in the Kallayanpur slum area, there are no open spaces, recreational sites and playgrounds for high density of population and settlements. More than $75 \%$ of slum dwellers are unsatisfied with not existing any open space because these kinds of people have no facilities to pace, even after expanding the highest amount of money per square feet among all dwellers of the city (Fig. 7).

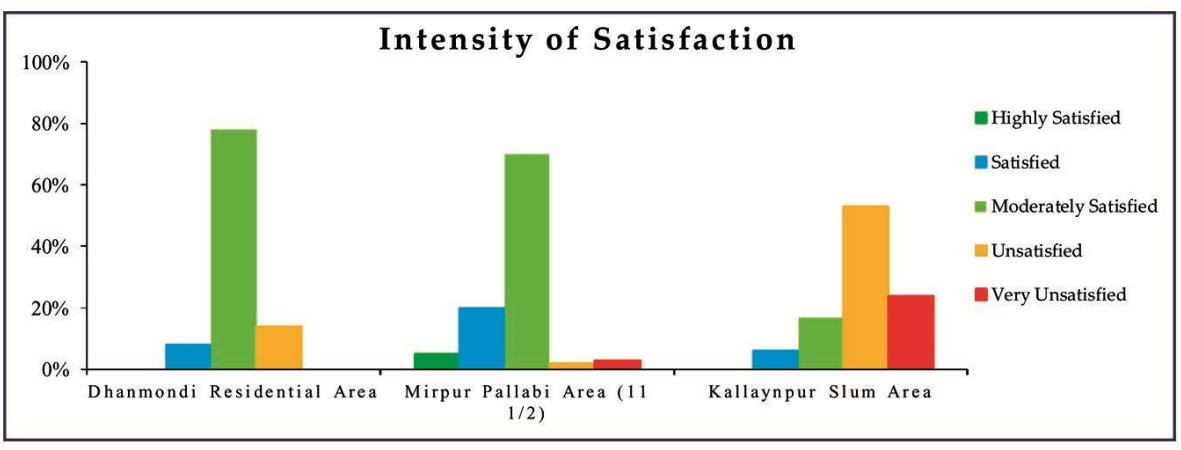

Fig. 7. Comparative study of satisfaction about open space.

Source: Field Study, 2018

Only 23\% of dwellers of this area express their middling satisfaction because of the remaining small school playground along with the south-east corner of the slum. And the slum children get access to play in the playground only after school breaks up in the afternoon and on holiday. Otherwise, children use mosque premises as their recreation place and playground. There is also a water body, called 'Jhil' by local people, full of wastage and garbage. Hence the dream for open space is just a joke for them. But all the slum dwellers demand a recreational site and a playground for their children's mental refreshment. 


\section{Conclusions and Recommendations}

This research investigates social perceptions of environmental hazards and risks and their causal interaction to other challenges in the study areas of Dhaka Metropolitan Area, Bangladesh. The findings expose that the intensity of environmental threats and challenges varies mainly according to their residential location, income, and administrative services. The study demonstrated that existing social and infrastructural conditions are primarily responsible for aggravating of people's vulnerability in the study areas to earthquake disasters and other associated risks. A large number of residents of high and middle-income residential areas (more than 65\%) in our study live in planned but disorganized multistoried buildings, which are more prone to earthquakes, fire, waterlogging, and pollutions. On the contrary, slum dwellers are highly exhausted and frightened owing to fire hazards than any other challenges. These dwellers are also highly vulnerable to air, water, and noise pollution, which directly affecting their health. Furthermore, the severity of environmental triggers has crossed a threshold that citizens cannot simply disregard. The findings indicated that the crucial stressors accompanied by noise, air, dust, and water pollution results from unplanned consumption of environmental resources.

Although this research has sought to examine environmental issues on multiple scales, environmental problems in households and neighborhoods are often indistinguishable. Indeed, they are also mutually inclusive; for example, neighborhood drainage congestion affects the mosquito threat. There is a two-way mechanism at work here, as household waste that is not properly disposed of that could be stored in the drains of the area, affecting sewage congestion and, in turn, raising the risk of infestation by insects, particularly mosquitoes. However, the main issue is not so much the attitude of householders as the fact that inadequate service provision and limited maintenance leave them with few alternatives. In addition, a particular issue for lower-income communities in DMA is poorly built environmental infrastructure, with the absence of structured infrastructure coverage for underprivileged communities and households impeding the resolving of health-related problems. This condition reflects the isolation and inequality of the urban poor, who, as a result of the under-supply of infrastructure at the household level, suffer from the most pervasive environmental health issues. It can also be emphasized that there are certain facets of a sustainable residential or community environment that Nongovernmental Organizations or Aid Agencies cannot solve without government intervention, such as the electricity shortage, low quality housing and, above all, the scarcity of citywide infrastructure (roads, piped water supplies, drainage and sewerage systems). 
From the observation, the study also found that the vast majority of survey respondents were not completely ready for a potential earthquake and fire hazards that are likely to occur in or around Dhaka Metropolitan Area in the foreseeable future. This implies that they do not perceive environmental hazards and risks as a threat to their lives. On the opposite, a good environmental condition often influences the thoughts and decisions of individuals, which typically determines human perceptions. Furthermore, it is crucial to consider the socio-spatial differences in people's attitudes that ultimately influence and dictate people's behaviors as well as environmental activism. Therefore, it is recommended that responsible and relevant stakeholders (such as the Ministry of Disaster Management and Relief, the Ministry of Forests, Environment and Climate Change, the Dhaka City Corporation, civil society, etc.) should immediately take effective steps to improve the resilience and capability of citizens in order to deter large-scale damage caused by earthquakes and other risks. In addition, these stakeholders should synergize efforts to develop enlightenment initiatives and introduce policies that could increase awareness among residents about environmental threats and risks resulting from their living conditions. Particularly, vulnerability has four dimensions, such as human, social, economic, and environmental dimensions. So, we assume that any analysis that looks at the problem in depth must, in any sense, consider a multidimensional research approach to the problem.

\section{References}

Agarwal, S. and S. Taneja. 2005. All Slums are Not Equal: Child Health Conditions among the Urban Poor. Indian Pediatrics 42(3): 233-244. https://nbn-resolving.org/urn:nbn: de:0168ssoar-46838-7

Ahmed, I. 2014. Factors in building resilience in urban slums of Dhaka, Bangladesh. Procedia Economics and Finance, 18: 745-753. https://doi.org/10.1016/S2212-5671(14)00998-8

Ahmed, T.U., G.M. Saifur Rahman, K. Bashar, M. Shamsuzzaman, S. Samajpati, S. Sultana, M.I. Hossain, N.N. Banu and A.M.S. Rahman. 2007. Seasonal prevalence of dengue vector mosquitoes in Dhaka city, bangladesh. Bangladesh J. Zool. 35(2): 205-212.

Akanda, A.S. and F. Hossain. 2012. The climate-water-health nexus in emerging megacities. Eos, Transactions American Geophysical Union 93(37): 353-354. https://doi.org/10.1029/ 2012EO370001

Akimoto, H. (2003). Global Air Quality and Pollution. Science, 302(5651), 1716-1719. https://doi.org/10.1126/science.1092666

Alam, G.M.J. 2009. Environmental pollution of Bangladesh - it's effect and control. International Conference on Mechanical Engineering 2009 (ICME2009), 51, 6.

Alam, M.J.B. and G.N. Baroi. 2004. Fire hazard categorization and risk assessment for Dhaka city in GIS framework. Journal of Civil Engineering (IEB) 32(1): 35-45.

Alam, M. and M.D.G. Rabbani. 2007. Vulnerabilities and responses to climate change for Dhaka. Environment and Urbanization 19(1): 81-97. https://doi.org/10.1177/0956247807076911 
City dwellers' perception of environmental hazards

Alamgir, M., M. Jabbar and M. Islam. 2009. Assessing the livelihood of slum dwellers in Dhaka city. Journal of the Bangladesh Agricultural University 7(2): 373-380. https://doi.org/ 10.3329/jbau.v7i2.4749.

Balakrishnan, K., S. Dey, T. Gupta, R.S. Dhaliwal, M. Brauer, A.J. Cohen, J.D. Stanaway, G. Beig, T.K. Joshi, A.N. Aggarwal, Y. Sabde, H. Sadhu, J. Frostad, K. Causey, W. Godwin, D.K. Shukla, G.A. Kumar, C.M. Varghese, P. Muraleedharan and Dandona. 2019. The impact of air pollution on deaths, disease burden, and life expectancy across the states of India: the Global Burden of Disease Study 2017. The Lancet Planetary Health, 3(1). https://doi.org/ $10.1016 /$ S2542-5196(18)30261-4

Bashar, K. 2006. Status and distribution of vector mosquito fauna in Jahangirnagar University (JU) campus. Bangladesh Journal of Life Science, 18(2): 35-44.

Bashar, K., H.M. Al-Amin, M.S. Reza, M. Islam, Asaduzzaman and T.U. Ahmed. 2012. Sociodemographic factors influencing knowledge, attitude and practice (KAP) regarding malaria in Bangladesh. BMC Public Health 12(1). https://doi.org/10.1186/1471-2458-12-1084

Bashar, K., F.F. Rain and M. Jesmin. 2014. Surveillance of mosquitoes in some selected parks and gardens of Dhaka city, Bangladesh. International Journal of Mosquito Research 1(2): 5.

Bashar, K., M. Shamsuzzaman and A.K. Chowdhury. 2006. Container Breeding Mosquitoes in Dhaka city, Bangladesh. Bangladesh Journal of Life Science 18(1): 69-78.

Begum, B. A., Biswas, S. K., \& Nasiruddin, M. (2010). Trend and spatial distribution of air particulate matter pollution in Dhaka City. Journal of Bangladesh Academy of Sciences, 34(1), 33-48.

Bhattarai, K., \& Conway, D. (2010). Urban Vulnerabilities in the Kathmandu Valley, Nepal: Visualizations of Human/Hazard Interactions. Journal of Geographic Information System 02(02). https://doi.org/10.4236/jgis.2010.22012

Bird, D.K., G. Gisladottir and D. Dominey-Howes. 2009. Resident perception of volcanic hazards and evacuation procedures. Natural Hazards and Earth System Science 9(1): https://doi.org/10.5194/nhess-9-251-2009

Blanco, H., M. Alberti, A. Forsyth, K.J. Krizek, D.A. Rodríguez, E. Talen and C. Ellis. 2009. Hot, congested, crowded and diverse: Emerging research agendas in planning. Progress in Planning 71(4): 153-205. https://doi.org/10.1016/j.progress.2009.03.001

Boadi, K., M. Kuitunen, K. Raheem and K. Hanninen. 2005. Urbanisation Without Development: Environmental and Health Implications in African Cities. Environment, Development and Sustainability 7(4): 465-500. https://doi.org/10.1007/s10668-004-5410-3

Braun, B. and T. Aßheuer. 2011. Floods in megacity environments: vulnerability and coping strategies of slum dwellers in Dhaka/Bangladesh. Natural Hazards 58(2): 771-787. https://doi.org/10.1007/s11069-011-9752-5

Brecht, H., U. Deichmann and H.G. Wang. 2013. A Global Urban Risk Index. In: Policy Research Working Papers. The World Bank. http://elibrary.worldbank.org/doi/book/10.1596/18139450-6506

Chen, H., B. Jia and S.S.Y. Lau. 2008. Sustainable urban form for Chinese compact cities: Challenges of a rapid urbanized economy. Habitat International 32(1): 28-40. https://doi. org/10.1016/j.habitatint.2007.06.005

Chepesiuk, R. 2003. Mosquito mismanagement? Environmental Health Perspectives, 111(12): https://doi.org/10.1289/ehp.111-a636b

Chowdhury, F.I., A. Kabir, A. Das, S.M. Mukerrama and S. Masud. 2012. Chikungunya Fever: An Emerging Threat to Bangladesh. Journal of Medicine 13(1): 60-64. https://doi.org/ 10.3329/jom.v13i1.10052 
Claret, A., E. Baranoski and M. Felicetti. 2012. An evolutionary approach for fire risk assessment in Brazilian slums. Journal of Fire Protection Engineering 22(1): 11-21. https://doi.org/ $10.1177 / 1042391511426216$

Dana, T. 2011. Unhygienic living conditions and health problems: A study in selected slums of Dhaka city. OIDA International Journal of Sustainable Development 2(11): 27-34.

Dewan, A.M., M.H. Kabir, K. Nahar and M.Z. Rahman. 2012. Urbanisation and environmental degradation in Dhaka metropolitan area of Bangladesh. International Journal of Environment and Sustainable Development 11(2): https://doi.org/10.1504/IJESD.2012.049178

Dhar-Chowdhury, P., C.E. Haque and S.M. Driedger. 2016. Dengue Disease Risk Mental Models in the City of Dhaka, Bangladesh: Juxtapositions and Gaps Between the Public and Experts. Risk Analysis 36(5). https://doi.org/10.1111/risa.12501

Farah, S., M. Karim, N. Akther, M. Begum and N. Begum. 2015. Knowledge and Practice of Personal Hygiene and Sanitation: A Study in Selected Slums of Dhaka City. Delta Medical College Journal 3(2). https://doi.org/10.3329/dmcj.v3i2.24425

Gautam, O.P., Y. Velleman, K.P. Paudel, M. Dhimal and V. Curtis. 2017. Water, sanitation, and hygiene interventions: an urgent requirement in post-flood Nepal. The Lancet Infectious Diseases 17(11): 1118-1119. https://doi.org/10.1016/S1473-3099(17)30569-8

Goyal, S. K., Ghatge, S. V., Nema, P., \& M. Tamhane, S. (2006). Understanding Urban Vehicular Pollution Problem Vis-a-Vis Ambient Air Quality - Case Study of a Megacity (Delhi, India). Environmental Monitoring and Assessment, 119(1-3), 557-569. https://doi.org/ 10.1007/s10661-005-9043-2

Gulis, G., J.A.A. Mulumba, O. Juma and B. Kakosova. 2004. Health status of people of slums in Nairobi, Kenya. Environmental Research 96(2): 219-227. https://doi.org/10.1016/j.envres. 2004.01.016

Guttikunda, S.K., B.A. Begum and Z. Wadud. 2013. Particulate pollution from brick kiln clusters in the Greater Dhaka region, Bangladesh. Air Quality, Atmosphere \& Health, 6(2): 357-365. https://doi.org/10.1007/s11869-012-0187-2

Guttikunda, S.K. and R. Goel. 2013. Health impacts of particulate pollution in a megacity-Delhi, India. Environmental Development 6,: 8-20. https://doi.org/10.1016/j.envdev.2012.12.002

Habib, K.M.N. and J.B. Alam. 2003. Effects of alternative transportation options on congestion and air pollution in Dhaka city. Journal of Civil Engineering 31(2): 165-175.

Halder, J. and N. Islam. 2015. Water Pollution and its Impact on the Human Health. Journal of Environment and Human 2(1): 36-46. https://doi.org/10.15764/EH.2015.01005

Halstead, S.B. 1966. Mosquito-borne haemorrhagic fevers of South and South-East Asia. Bulletin of the World Health Organization 35(1): 3-15.

Haque, A. and Y. Asami. 2011. Optimizing Urban Land-Use Allocation: Case Study of Dhanmondi Residential Area, Dhaka, Bangladesh. Environment and Planning B: Planning and Design 38(3): 388-410. https://doi.org/10.1068/b35041

Hassan, M., R. Hassan, M.A. Mahmud, H.I. Pia, M.A. Hassan and M.J. Uddin. 2017. Sewage Waste Water Characteristics and Its Management in Urban Areas- A Case Study at Pagla Sewage Treatment Plant, Dhaka. Urban and Regional Planning 2(3): 13. https://doi.org/10.11648/j.urp.20170203.11

Hassan, R., M.M. Rahman, M. Moniruzzaman, A. Rahim, S. Barua, R. Biswas, P. Biswas, S.G.M. Mowla and M.A.J. Chowdhury. 2014. Chikungunya - an emerging infection in Bangladesh: a case series. Journal of Medical Case Reports 8(1): https://doi.org/10.1186/1752-1947-8-67 
City dwellers' perception of environmental hazards

Hosamane, S.N. and D.G.P. Desai. 2007. Urban air pollution trend in india - present scenario. International Journal of Innovative Research in Science, Engineering and Technology 2(8): 3738-37479.

Hossain, S. 2006. Social characteristics of a megacity: a case of Dhaka City, Bangladesh. TASA Conference 2006, 10.

Islam, M.S., M.M.P. Rana and R. Ahmed. 2014. Environmental perception during rapid population growth and urbanization: A case study of Dhaka city. Environment, Development and Sustainability, 16(2): https://doi.org/10.1007/s10668-013-9486-5

Islam, M, A. Mahmud and S.M.D. Islam. 2015a. Open Space Management of Dhaka City, Bangladesh: A Case Study on Parks and Playgrounds. International Research Journal of Environment Sciences 4(12): 118-126.

Islam, Md., M. Uddin, S. Tareq, M. Shammi, A. Kamal, T. Sugano, M. Kurasaki, T. Saito, S. Tanaka and H. Kuramitz. 2015b. Alteration of Water Pollution Level with the Seasonal Changes in Mean Daily Discharge in Three Main Rivers around Dhaka City, Bangladesh. Environments 2(4): 280-294. https://doi.org/10.3390/environments2030280

Islam, N., G. Angeles, A. Mahbub, P. Lance and N.I. Nazem. 2006. Slums of urban Bangladesh: mapping and census 2005. Centre for Urban Studies, National Institute of Population Research and Training, and MEASURE Evaluation.

Islam, S., H.A. Begum and N.Y. Nili. 2010. Bacteriological Safety Assessment of Municipal Tap Water and Quality of Bottle Water in Dhaka City: Health Hazard Analysis. Bangladesh Journal of Medical Microbiology 4(1): https://doi.org/10.3329/bjmm.v4i1.8462

Jahan, M. 2012. Impact of rural urban migration on physical and social environment: The case of Dhaka city. International Journal of Development and Sustainability 1(2): 186-194.

Kamal, M. and S.A.K. Pramanik. 2015. Factors Affecting Customers to Buy Apartments in Dhaka City. Daffodil International University Journal of Business and Economics 9(2): 37-49.

Kamruzzaman, M. and M.A. Hakim. 2016. Socio-economic Status of Slum Dwellers: An Empirical Study on the Capital City of Bangladesh. American Journal of Business and Society 1(2): 1318. http://www.aiscience.org/journal/ajbs

Karim, N. 1995. Disasters in Bangladesh. Natural Hazards 11(3): 247-258. https://doi.org/10. 1007/BF00613409

Kampa, M., \& Castanas, E. (2008). Human health effects of air pollution. Environmental Pollution, 151(2), 362-367. https://doi.org/10.1016/j.envpol.2007.06.012

Khan, H.R., M.M. Islam, T. Akter, M.R. Karim and M.S. Farid. 2014. Diversity of mosquitoes and their seasonal fluctuation in two wards of Dhaka city. Dhaka University Journal of Biological Sciences 23(1): 17-26. https://doi.org/10.3329/dujbs.v23i1.19822

Khan, M. 2014. Study of Open Spaces in the Context of Dhaka City for Sustainable Use: A Syntactic Approach. International Journal of Engineering and Technology 6(3): https://doi.org/10.7763/ijet.2014.v6.704

Khan, S.I., A. Khan, M.N.I. Sarker, N. Huda, M.R. Zaman, A.B.M. Nurullah and M.Z. Rahman. 2018. Traffic Congestion in Dhaka city: Suffering for City Dwellers and Challenges for Sustainable Development. In European Journal of Social Sciences (Vol. 57).

Khatun, H. and S. Islam. 2015. Awareness and Preparedness of Disaster in Bangladesh: A Study of Dhaka City Dwellers. Social Science Review, The University Studies (Part-D 32(1): 57-70. http://geoenv.du.ac.bd/wp-content/uploads/2017/08/Awareness-and-Preparedness-ofDisasters-in-Bangladesh-A-Study-of-Dhaka-City-Dwellers.pdf 
Latif, M.B., A. Irin and J. Ferdaus. 2016. Socio-economic and health status of slum dwellers of the Kalyanpur slum in Dhaka city. Bangladesh Journal of Scientific Research 29(1): 73-83. https://doi.org/10.3329/bjsr.v29i1.29760

Maniruzzaman, K.M. and Q. Haque. 2007. Fire hazard in Dhaka City: A case study of the service area of Mohammadpur fire station. Urbanization in Bangladesh: Patterns, Issues and Approaches to Planning; Jahan, S., Maniruzzaman, KM, Eds, 96-104.

Marimuthu, P., G.N. Rao, M.K. Sharma and R.D. Pandian. 2016. Perceptions on Public Health Facilities by Slum Dwellers in the Metropolitan Cities of India. Health 08(01): 93-97. https://doi.org/10.4236/health.2016.81011

Mark, O., C. Jørgensen, M. Hammond, D. Khan, R. Tjener, A. Erichsen and B. Helwigh. 2018. A new methodology for modelling of health risk from urban flooding exemplified by cholera case Dhaka, Bangladesh. Journal of Flood Risk Management, 11: https://doi.org/ $10.1111 /$ jfr3.12182

McDonald, R.I., R.T.T. Forman and P. Kareiva. 2010. Open Space Loss and Land Inequality in United States' Cities, 1990-2000. PLoS ONE, 5(3): 9509. https://doi.org/10.1371/journal. pone.0009509

Mohit, M.A. 2012. Bastee settlements of Dhaka City, Bangladesh: a review of policy approaches and challenges ahead. Procedia-Social and Behavioral Sciences 36: 611-622.

Mowla, Q.A. and M.S. Islam.. 2013. Natural drainage system and water logging in Dhaka: measures to address the problems. Journal of Bangladesh Institute of Planners 6: 23-33.

Olowoporoku, O. 2018. Echoes from the coast: Assessment of residents' perception of environmental hazards and risks in coastal communities of Nigeria. Environmental Quality Management 28(1): https://doi.org/10.1002/tqem.21573

Parvin, G.A., S.M.R. Ahsan and R. Shaw. 2013. Urban Risk Reduction Approaches in Bangladesh. In R. Shaw, F. Mallick and A. Islam (Eds.), Disaster Risk Reduction Approaches in Bangladesh (pp. 235-257). Springer Japan. http://link.springer.com/10.1007/978-4-43154252-0_11

Paul, B.K. and R.H. Bhuiyan. 2010. Urban earthquake hazard: Perceived seismic risk and preparedness in Dhaka City, Bangladesh. Disasters 34(2): https://doi.org/10.1111/j.14677717.2009.01132.x

Phillips, D.R., O.L. Siu, A.G.O. Yeh and K.H.C. Cheng. 2004. Factors influencing older persons' residential satisfaction in big and densely populated cities in Asia: A case study in Hong Kong. Ageing International 29(1): https://doi.org/10.1007/s12126-004-1009-0

Rahman, M. Z. and S.A. Siddiquee. 2012. Urban forestry for green city. The Daily Star. https://www.thedailystar.net/news-detail-250707

Rahman, Maksudur M., G. Haughton and A.E.G. Jonas. 2010. The challenges of local environmental problems facing the urban poor in Chittagong, Bangladesh: A scale-sensitive analysis. Environment and Urbanization 22(2). https://doi.org/10.1177/0956247810377560

Rahman, Md Mahbubur, A.B.M. Abdullah and M.W. Murad. 2018. Community perceptions of and vulnerability to earthquake disaster: Insights from the City of Dhaka, Bangladesh. Journal of Environmental Assessment Policy and Management 20(4): https://doi.org/10.1142/ S1464 333218500138

Rasid, H. 1996. Impact assessments from survey of floodplain residents: The case of the dhakanarayanganj-demra (DND) project, Bangladesh. Impact Assessment, 14(2): https://doi.org/ 10.1080/07349165.1996.9725893

Rout, N.R. and R.B. Bhagat. 2012. City dwellers' perception of urban environment in Bhubaneswar, India and its correlates. Built-Environment Sri Lanka 11(1): 7. https:// doi.org/10.4038/besl.v11i1.3071 
City dwellers' perception of environmental hazards

Salam, A., Hossain, T., Siddique, M. N. A., \& Alam, A. M. S. (2008). Characteristics of atmospheric trace gases, particulate matter, and heavy metal pollution in Dhaka, Bangladesh. Air Quality, Atmosphere \& Health, 1(2), 101-109. https://doi.org/10.1007/s11869-008-0017-8

Schwarzenbach, R.P., T. Egli, T.B. Hofstetter, U. von Gunten and B. Wehrli. 2010. Global Water Pollution and Human Health. Annual Review of Environment and Resources 35(1): 109-136. https://doi.org/10.1146/annurev-environ-100809-125342

Sheuya, S. A. (2008). Improving the Health and Lives of People Living in Slums. Annals of the New York Academy of Sciences 1136(1): 298-306. https://doi.org/10.1196/annals.1425.003

Snehalatha, K.S., K.D. Ramaiah, K.N. Vijay Kumar and P.K. Das. 2003. The mosquito problem and type and costs of personal protection measures used in rural and urban communities in Pondicherry region, South India. Acta Tropica 88(1): 3-9. https://doi.org/10.1016/S0001706X(03)00155-4

Sundari, S. 2003. Quality of life of migrant households in urban slums. 537-552. files/490/Sundari Quality of life of migrant households in urban slu.pdf

Talukdar, P.K., M. Rahman, M. Rahman, A. Nabi, Z. Islam, M.M. Hoque, H.P. Endtz, and M.A. Islam. 2013. Antimicrobial Resistance, Virulence Factors and Genetic Diversity of Escherichia coli Isolates from Household Water Supply in Dhaka, Bangladesh. PLoS ONE, 8(4), e61090. https://doi.org/10.1371/journal.pone.0061090

The Daily Star. 2016a. Blaze follows stalled drive. The Daily Star. https://www.thedailystar.net/ frontpage/mysterious-fire-follows-failed-eviction-drive-205951

The Daily Star. 2016b. Kalyanpur slum fire doused. The Daily Star. https://www.thedailystar. net/city/fire-kalyanpur-slum-205606

Thomas, B. 2007. A Wind Powered, White LED Lighting System for the Kibera Slum of Nairobi. International Journal for Service Learning in Engineering, Humanitarian Engineering and Social Entrepreneurship 2(1): https://doi.org/10.24908/ijsle.v2i1.2089

United Nations. 2019. World Urbanization Prospects: the 2018 Revision. United Nations Department of Economic and Social Affairs, Population Division, Online edition. https://population.un.org/wup/Publications/Files/WUP2018-Report.pdf

Wolch, J.R., J. Byrne and J.P. Newell. 2014. Urban green space, public health, and environmental justice: The challenge of making cities "just green enough." Landscape and Urban Planning, 125: 234-244. https://doi.org/10.1016/j.landurbplan.2014.01.017

World Health Organisation. 2018. WHO Global Ambient Air Quality Database (update 2018). Ambient Air Quality Database (Update 2018), update 2018.

World Health Organization (WHO). 2014. Ambient (outdoor) air pollution database, by country and city. World Health Organization, Geneva.

Zhang, X., M. Hu, G. Chen and Y. Xu. 2012. Urban Rainwater Utilization and its Role in Mitigating Urban Waterlogging Problems - A Case Study in Nanjing, China. Water Resources Management 26(13): 3757-3766. https://doi.org/10.1007/s11269-012-0101-6

(Revised copy received on 23.03.2021) 